\title{
Phosphodiesterase-10A Inverse Changes in Striatopallidal and Striatoentopeduncular Pathways of a Transgenic Mouse Model of DYT1 Dystonia
}

\author{
Vincenza D'Angelo, ${ }^{1 *}$ Valentina Castelli, ${ }^{2 *}$ Mauro Giorgi, ${ }^{2}$ Silvia Cardarelli, ${ }^{2}$ Ilaria Saverioni, ${ }^{2}$ Francesca Palumbo, ${ }^{1}$

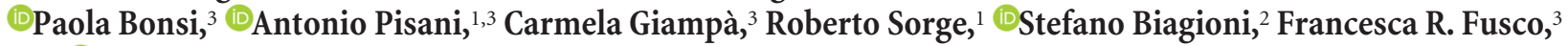 \\ and $\mathbb{C}^{-G i u s e p p e ~ S a n c e s a r i o}{ }^{1}$ \\ ${ }^{1}$ Department of Systems Medicine, Tor Vergata University of Rome, 00133 Rome, Italy, ${ }^{2}$ Department of Biology and Biotechnology “Charles Darwin," \\ Sapienza University of Rome, 00185 Rome, Italy, and ${ }^{3}$ Santa Lucia Foundation, 00179 Rome, Italy
}

We report that changes of phosphodiesterase-10A (PDE10A) can map widespread functional imbalance of basal ganglia circuits in a mouse model of DYT1 dystonia overexpressing mutant torsinA. PDE10A is a key enzyme in the catabolism of second messenger cAMP and cGMP, whose synthesis is stimulated by D1 receptors and inhibited by D2 receptors preferentially expressed in striatoentopeducuncular/substantia nigra or striatopallidal pathways, respectively. PDE10A was studied in control mice (NT) and in mice carrying human wild-type torsinA (hWT) or mutant torsinA (hMT). Quantitative analysis of PDE10A expression was assessed in different brain areas by rabbit anti-PDE10A antibody immunohistochemistry and Western blotting. PDE10A-dependent cAMP hydrolyzing activity and PDE10A mRNA were also assessed. Striatopallidal neurons were identified by rabbit anti-enkephalin antibody.

In NT mice, PDE10A is equally expressed in medium spiny striatal neurons and in their projections to entopeduncular nucleus/ substantia nigra and to external globus pallidus. In hMT mice, PDE10A content selectively increases in enkephalin-positive striatal neuronal bodies; moreover, PDE10A expression and activity in hMT mice, compared with NT mice, significantly increase in globus pallidus but decrease in entopeduncular nucleus/substantia nigra. Similar changes of PDE10A occur in hWT mice, but such changes are not always significant. However, PDE10A mRNA expression appears comparable among NT, hWT, and hMT mice.

In DYT1 transgenic mice, the inverse changes of PDE10A in striatoentopeduncular and striatopallidal projections might result over time in an imbalance between direct and indirect pathways for properly focusing movement. The decrease of PDE10A in the striatoentopeduncular/nigral projections might lead to increased intensity and duration of D1-stimulated cAMP/cGMP signaling; conversely, the increase of PDE10A in the striatopallidal projections might lead to increased intensity and duration of D2-inhibited cAMP/cGMP signaling.

Key words: basal ganglia; cAMP; dopamine receptors; dystonia; hyperkinetic disorder; PDE10A

Significance Statement

In DYT1 transgenic mouse model of dystonia, PDE10A, a key enzyme in cAMP and cGMP catabolism, is downregulated in striatal projections to entopeduncular nucleus/substantia nigra, preferentially expressing D1 receptors that stimulate cAMP/cGMP synthesis. Conversely, in DYT1 mice, PDE10A is upregulated in striatal projections to globus pallidus, preferentially expressing D2 receptors that inhibit cAMP/cGMP synthesis. The inverse changes to PDE10A in striatoentopeduncular/substantia nigra and striatopallidal pathways might tightly interact downstream to dopamine receptors, likely resulting over time to increased intensity and duration respectively of D1-stimulated and D2-inhibited cAMP/cGMP signals. Therefore, PDE10A changes in the DYT1 model of dystonia can upset the functional balance of basal ganglia circuits, affecting direct and indirect pathways simultaneously.

\section{Introduction}

Dystonia is a heterogeneous movement disorder occurring either in focal or generalized forms. It is characterized by sustained or intermittent muscle contractions causing abnormal, often repetitive, movements, postures, or both (Fahn et al., 1998; Albanese et al., 2013). The most common and severe isolated dystonia is 
caused by a 3 bp deletion ( $\triangle \mathrm{GAG}$ ) in the coding region of the TOR1A (DYT1) gene, which results in a defective protein called torsinA (Ozelius et al., 1997). Ultrastructural studies are consistent with a presynaptic localization of torsinA protein in the adult striatum and in other regions, suggesting a role of torsin $\mathrm{A}$ in the modulation of signal transmission (Augood et al., 2003; Rostasy et al., 2003; Puglisi et al., 2013). However, the physiological function of torsinA is unclear, though it has been proposed to perform chaperone-like functions and assist in protein trafficking, as well as participate in membrane fusion, secretory processing, and nuclear envelope dynamics (Goodchild et al., 2013).

Neuropathological investigations have not shown consistent histopathological abnormalities (Albanese et al., 2013) and the immunostaining pattern of torsinA in patients with DYT1 dystonia has not been found to be discernibly different from that in normal brains (Fahn et al., 1998). Moreover, torsinA immunoreactivity is widely distributed throughout striatal neuron populations without variation of the labeling intensity in a specific population of striatal neurons in transgenic mouse models carrying the gene of human wild-type or mutated torsinA (Martella et al., 2009).

Similarly, it is not clear which brain regions are primarily involved in most forms of dystonia, as significant neurodegeneration could not be documented in any specific brain areas (Fahn et al., 1998; Standaert, 2011). Thus, brain regions possibly involved in dystonia are thought to have functional rather than structural abnormalities. Indeed, despite the lack of neuropathological indications, neurophysiological and neuroimaging studies, as well as new genetic insights, suggest that functional abnormalities in the basal ganglia constitute the basis of dystonia pathophysiology (Rondot, 1991; Kanovský, 2002; Defazio et al., 2007; Uluğ et al., 2011; Goodchild et al., 2013).

On that basis, we hypothesized that phosphodiesterase 10A (PDE10A), a key enzyme in the catabolism of the second messenger cAMP and cGMP in the brain (Soderling et al., 1999), may be a good indicator of any functional changes arising in basal ganglia circuits and may be involved in the pathophysiology of dystonia. Of note, PDE10A is differentially affected in the basal ganglia of experimental Parkinson's and Huntington's disease models (Hebb et al., 2004; Giorgi et al., 2011; Leuti et al., 2013). Moreover, recent PET imaging studies show loss of striatal and pallidal PDE10A in patients with Huntington's disease (Ahmad et al., 2014; Niccolini et al., 2015b) or Parkinson's disease (Niccolini et al., 2015a ).

PDE10A is an isozyme with unique distribution in the basal ganglia, within the cell body of medium spiny neurons in the striatum and nucleus accumbens, and within their axons/terminals in the globus pallidus, the entopeduncular nucleus, and the substantia nigra pars reticulata (Seeger et al., 2003; Xie et al., 2006; Giorgi et al., 2011). The globus pallidus and the entopeduncular nucleus in rodents correspond to the external and the internal globus pallidus in humans, respectively, representing nodal points of the so-called indirect and direct pathways of basal ganglia circuits (Albin et al., 1989). The striatal projections to the external and internal globus pallidus have opposite effects on basal ganglia functions, the one reducing and the other facilitat-

The authors declare no competing financial interests.

*V.D. and V.C contributed equally to this work.

Correspondence should be addressed to Giuseppe Sancesario, Department of Systems Medicine, Tor Vergata University of Rome, 1 Montpellier St., 00133 Rome, Italy. E-mail: sancesario@med.uniroma2.it.

DOI:10.1523/JNEUROSCI.3207-15.2016

Copyright $\odot 2017$ the authors $\quad 0270-6474 / 17 / 372113-13 \$ 15.00 / 0$ ing the motor activities (Albin et al., 1989; Alexander and Crutcher, 1990; DeLong, 1990). We evaluated whether torsinA may specifically affect PDE10A expression and activity in basal ganglia circuits in transgenic mouse models overexpressing human wild-type torsinA or human DYT1 torsinA mutation.

\section{Materials and Methods}

Transgenic mice, generated as previously reported (Sharma et al., 2005), were bred at the Santa Lucia Foundation Animal Facility. The mouse genotype was confirmed as previously described (Martella et al., 2009; Sciamanna et al., 2011). All efforts were made to minimize the number of animals used and any potential suffering. Treatment and handling of mice were performed in compliance with both European Council and Italian guidelines (86/609/EEC; Legislative Decree 116/1992). The experimental protocols were approved by the Animal Ethics Committee of Tor Vergata University of Rome (Ministerial Decree 153/2001-A and 43/2002-A), and by the Santa Lucia Foundation Animal Care and Use Committee (Ministerial Decree 9/2006-A), and authorized by the Italian Ministry of Health (protocol no. 07/2011).

Three groups of male animals were studied: nontransgenic control mice (NT mice), transgenic mice carrying the gene of human wild-type torsinA (hWT mice), and transgenic mice carrying the gene of human mutated torsinA (hMT mice).

For morphological studies, animals were deeply anesthetized with tiletamine/zolazepam $(80 \mathrm{mg} / \mathrm{kg})$ and xylazine $(10 \mathrm{mg} / \mathrm{kg})$ and transcardially perfused with $1 \%$ heparin in $50 \mathrm{ml}$ of $0.1 \mathrm{M}$ sodium phosphate buffer, and with $250 \mathrm{ml}$ of $4 \%$ paraformaldehyde in $0.1 \mathrm{M}$ sodium phosphate buffer, $\mathrm{pH}$ 7.4. Brains were immediately removed and postfixed in the same fixative solution overnight at $4^{\circ} \mathrm{C}$. Using an Oxford vibratome, $40-\mu \mathrm{m}$-thick coronal brain sections were cut across the entire rostrocaudal extent of the basal ganglia, collected, and stored at $4^{\circ} \mathrm{C}$ in $0.1 \mathrm{M}$ phosphate buffer, which contained $0.02 \%$ sodium azide.

For biochemical studies, animals were killed by cervical dislocation, and their brains were rapidly removed and placed on an ice-cold plate, as previously described (Giorgi et al., 2008). Thick brain sections were cut with an Oxford vibratome, and the caudate-putamen, globus pallidus, substantia nigra, and entopeduncular nucleus (Paxinos and Franklin, 2012) were dissected out rapidly from both hemispheres, promptly frozen in liquid nitrogen, and stored at $-80^{\circ} \mathrm{C}$. Although PDE10A is selectively located in the substantia nigra pars reticulata, this area cannot be macroscopically identified and dissected separately from the pars compacta in brainstem sections, and therefore both areas were analyzed together.

Selected brain regions were homogenized using a glass homogenizer ( 15 strokes, $\left.4^{\circ} \mathrm{C}\right)$ in $20 \mathrm{~mm}$ Tris- $\mathrm{HCl}$ buffer, $\mathrm{pH}$ 7.2, which contained $0.2 \mathrm{~mm}$ EGTA, $5 \mathrm{~mm} \beta$-mercaptoethanol, 2\% $(\mathrm{v} / \mathrm{v})$ antiprotease mixture, $1 \mathrm{~mm}$ PMSF, $5 \mathrm{~mm} \mathrm{MgCl}_{2}, 0.1 \%$ Triton X-100. The homogenates were centrifuged at $14,000 \times g$ for $30 \mathrm{~min}$ at $4^{\circ} \mathrm{C}$, and pellets were resuspended in the homogenization buffer and centrifuged at $14,000 \times g$ for $30 \mathrm{~min}\left(4^{\circ} \mathrm{C}\right)$. The first and second supernatants were then pooled and further processed for biochemical analysis.

Histology and PDE10A immunohistochemistry. Coronal brain sections, including the sensorimotor cerebral cortex, caudate-putamen, globus pallidus, entopeduncular nucleus, and substantia nigra were either stained with cresyl violet under standard procedures to evaluate the general tissue morphology, or processed using immunocytochemistry techniques for the identification of PDE10A-positive neurons and nerve fibers. Briefly, free-floating sections were washed three 
times in Tris-buffered saline, $\mathrm{pH}$ 7.4; endogenous peroxidase activity was inactivated by incubation for $5 \mathrm{~min}$ in Trisbuffered saline that contained $2 \% \mathrm{H}_{2} \mathrm{O}_{2}$. Sections were rinsed with Tris-buffered saline that contained $0.1 \%$ Triton X-100, and incubated with $2 \%$ normal goat serum, followed by overnight incubation at $4^{\circ} \mathrm{C}$ with the primary antibody rabbit antiPDE10A (1:200; FabGennix). The primary antibody was detected using a biotinylated secondary goat anti-rabbit antibody (Vectastain ABC kit, Vector Laboratories), and an avidin-horseradish peroxidase/diaminobenzidine $/ \mathrm{H}_{2} \mathrm{O}_{2}$ chromogen system (Sigma-Aldrich).

The specificity of the immunocytochemical reaction was confirmed by the absence of staining after omission of the primary antibodies. After the diaminobenzidine reaction, sections were rinsed with Tris-buffered saline, mounted on gelatin-coated slides, dehydrated, and coverslipped with Permount for light microscopy examination. Sections were observed and photographed with a light microscope (Olympus BX51) equipped with an automatic microcamera (Leica DC 300 F, Q550 IW Soft).

Morphometry and densitometric analysis. To evaluate the relative number of cells in the striatum, a light microscope was used (Olympus BX51). This was equipped with a $20 \times$ objective and with an automatic microcamera (Leica DC 300 F, Q550 IW Soft). An expert operator performed automatic morphological analysis using Quantimet Image Processing and Analysis System (Q550 IW Soft). Total cell counts per area were performed in two Nisslstained sections, including the cross-sectional areas of the striatum of three animals per group ( $1.4 \mathrm{~mm}$ anterior to $0.14 \mathrm{~mm}$ posterior to bregma; Paxinos and Franklin, 2012). The counting frame $\left(1.35 \times 10^{5} \mu \mathrm{m}^{2}\right)$ was randomly placed on the counting area that contained the dorsolateral part of the caudate-putamen. The total number of Nissl-stained cells (mean $\pm \mathrm{SD}$ ) were counted per unit test area $\left(1.35 \times 10^{5} \mu \mathrm{m}^{2}\right)$ and were expressed independently of the hemispheric laterality.

To evaluate the PDE10A content in brain sections, densitometry analysis of PDE10A immunoreaction staining intensity was evaluated in the different regions of the basal ganglia circuits of the three groups of animals (five sections per animal, three fields per area per section), using the Gray Scale Program of the Quantimet Image Processing and Analysis System (Q550 IW Soft). Values were expressed as means \pm SD of immunoreactive optical density per unit test area $\left(4.5 \times 10^{4}{\mu \mathrm{m}^{2}}^{2}\right)$ in the caudate-putamen, globus pallidus, entopeduncular nucleus, and substantia nigra.

Double immunofluorescence techniques and confocal microscopy. To evaluate distribution of PDE10A and enkephalin (Enk) in striatal neurons, the double immunofluorescence analysis was performed; it was targeted to hMT mice, which showed the most significant PDE10A changes compared with control NT mice in our study.

Briefly, free-floating sections of the caudate-putamen of three mice per group, $40 \mu \mathrm{m}$ thickness each, were incubated for $72 \mathrm{~h}$ at $4^{\circ} \mathrm{C}$ with a mixture of the following: (1) mouse monoclonal antiPDE10A antibody (24F3.F11, generous gift from Pfizer to Dr. Francesca R. Fusco) diluted 1:1000; (2) a mixture (1:200) of rabbit anti-leucine-Enk and rabbit anti-Met-Enk antibodies (Millipore Bioscience Research Reagents). Sections were then rinsed and subsequently incubated with goat anti-rabbit cyanine Cy2 (Cy2)-conjugated secondary antibody, and goat anti-mouse cyanine $\mathrm{Cy} 3$ (Cy3)-conjugated secondary antibody 1:50 in PBS (Jackson Immunoresearch) for $2 \mathrm{~h}$ at room temperature. Sections were mounted on gelatin-coated slides and coverslipped with Gel Mount.
The dorsolateral caudate-putamen was examined under an epi-illumination fluorescence microscope (Zeiss Axioskop 2) and a confocal laser scanning microscope (Zeiss LSM 510) with a $40 \times$ objective. PDE10A immunoreactivity was visualized by red $\mathrm{Cy} 3$ fluorescence. Enk immunoreactivity was visualized by green Cy2 fluorescence. Colocalization of Enk and PDE10A immunoreactivity was visualized by merged image in orange-yellow, and was rated as present or absent.

Enk-positive and Enk-negative cells colocalizing PDE10A were identified per microscopic field in the dorsolateral caudateputamen on three fields per area, three sections per animal, and three animals per group. The content of PDE10A fluorescence per cell was evaluated by Java image processing and ImageJ. Briefly, the cells of interest were selected using a drawing selection circle around the identifiable neuronal bodies, and the red color image of PDE10A fluorescence intensity was analyzed by converting each pixel in grayscale (0-255). The minimum and maximum gray values within the selection were detected, and the mean gray value (the sum of the gray values of all the pixels in the selection divided by the number of pixels) per cell was calculated.

PDE10A protein quantitative analysis. Western blotting was used for the quantitative analysis of PDE10A expression in the caudate-putamen, globus pallidus, substantia nigra, and entopeduncular nucleus. SDS-PAGE was performed on $9 \%$ slab gels (GE Healthcare), followed by transfer of the proteins to nitrocellulose membranes (Bio-Rad). Blots were incubated overnight at $4^{\circ} \mathrm{C}$ with rabbit anti-PDE10A antibody (1:2000; FabGennix), or mouse anti- $\beta$-actin (1:10,000; Sigma-Aldrich) as reference standard. A secondary goat anti-rabbit IgG alkaline phosphatase (1: 2000; Sigma-Aldrich) was used to reveal PDE10A immune complexes. Immunoreactive bands were stained with nitroblue tetrazolium $(0.3 \mathrm{mg} / \mathrm{ml})$ in the presence of 5-bromo-4-chloro-3indolyl-phosphate $(0.15 \mathrm{mg} / \mathrm{ml})$. Densitometry analysis of scanned blots was performed using the National Institutes of Health ImageJ version 1.29 program.

Phosphodiesterase activity assay. Phosphodiesterase (PDE) activity was measured at $30^{\circ} \mathrm{C}$ for $15 \mathrm{~min}$ (linearity period) with the two-step method described by Thompson and Appelman (1971), using $\left[{ }^{3} \mathrm{H}\right]$ cAMP (GE Healthcare). Aliquots of tissue extracts were incubated in $60 \mathrm{mM}$ HEPES, $\mathrm{pH}$ 7.2, assay buffer containing $0.1 \mathrm{~mm}$ EGTA, $5 \mathrm{~mm} \mathrm{MgCl} 2,0.5 \mathrm{mg} / \mathrm{ml}$ bovine serum albumin, and $30 \mu \mathrm{g} / \mathrm{ml}$ soybean trypsin inhibitor, in a final volume of 0.3 $\mathrm{ml}$. The reaction was started by adding tritiated substrate at a final concentration of $0.1 \mu \mathrm{M}\left[{ }^{3} \mathrm{H}\right]$ cAMP and stopped by adding 0.1 $\mathrm{ml}$ of $0.1 \mathrm{M} \mathrm{HCl}$. This low substrate concentration was chosen so that the activity of PDE with high cAMP affinity could be preferentially detected, like the PDE10A that hydrolyzes CAMP with a Michaelis constant $\left(K_{\mathrm{m}}\right)$ of $0.05 \mu \mathrm{M}$ but cGMP with a $K_{\mathrm{m}}$ of $3 \mu \mathrm{M}$. To evaluate PDE10A contribution to the total cAMP-PDE activity, we compared papaverine specificity and potency in inhibiting cyclic nucleotide hydrolysis in tissue extracts from the different strains of animals (Siuciak et al., 2006; Giorgi et al., 2011).

RNA extraction and real-time PCR. Total RNA was prepared using the TRI Reagent (Sigma-Aldrich), according to the manufacturer's instructions. Purified RNA was treated with RNase-free DNase I (Ambion). Two micrograms of RNA from each sample were reverse transcribed for $60 \mathrm{~min}$ at $37^{\circ} \mathrm{C}$ with $1.0 \mu \mathrm{g}$ of random hexamers (Promega) as primers and $200 \mathrm{U}$ of M-MLV reverse transcriptase (Promega).

Real-time PCR was performed on reverse-transcription (RT) products with the SsoFast EvaGreen Supermix (Bio-Rad) in a Lightcycler apparatus (Bio-Rad), following the manufacturer's instructions. Thermal cycling conditions consisted of an initial 


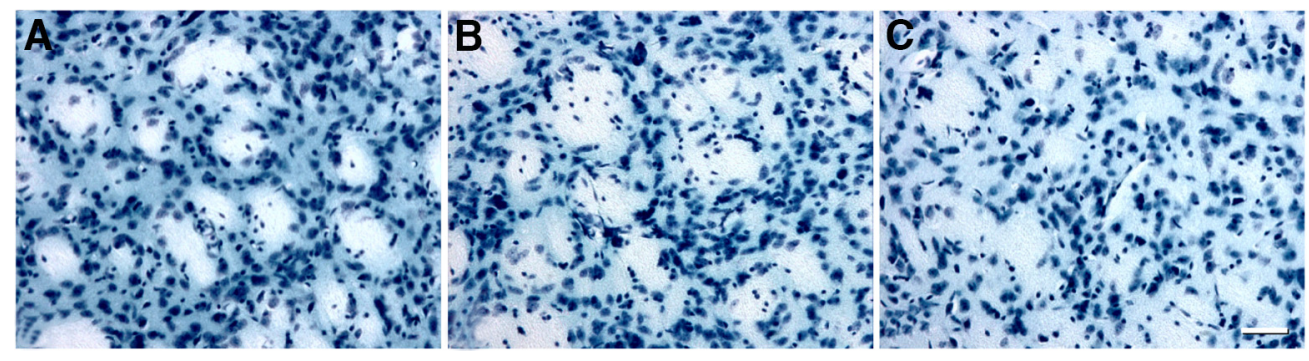

Figure 1. Low-power microphotographs of the caudate-putamen. Nissl-stained sections showing neurons and glia, stained in blue, distributed like patches among bundles of unstained white matter. $\boldsymbol{A}$, NT mice. $\boldsymbol{B}$, hWT mice. $\boldsymbol{C}$, hMT mice. Scale bar, $100 \mu \mathrm{m}$.
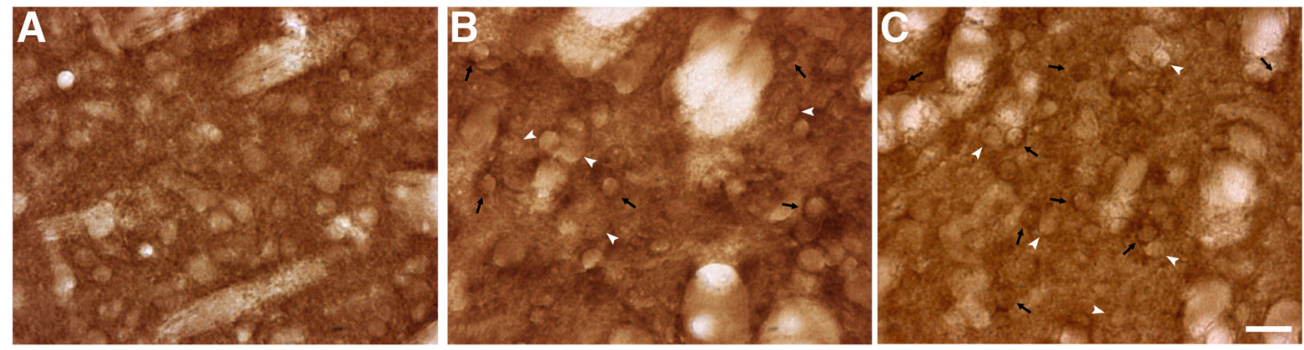

Figure 2. $\quad \boldsymbol{A}-\boldsymbol{C}$, Comparative PDE10A immunohistochemistry in striatal neurons of $(\boldsymbol{A})$ NT mice, $(\boldsymbol{B}) \mathrm{hWT}$ mice, and $(\boldsymbol{C}) \mathrm{hMT}$ mice. The white arrows point to striatal neurons with low PDE10A immunoreactivity; black arrows point to striatal neurons with high PDE10A immunoreactivity. Nuclei of neurons, small blood vessels, and bundles of white matter appear lightly stained or unstained. Scale bar, $50 \mu \mathrm{m}$.

denaturation step at $95^{\circ} \mathrm{C}$ for $1 \mathrm{~min}$, followed by 40 cycles at $95^{\circ} \mathrm{C}$ for $10 \mathrm{~s}, 60^{\circ} \mathrm{C}$ for $10 \mathrm{~s}$, and $72^{\circ} \mathrm{C}$ for $15 \mathrm{~s}$.

The threshold cycle $(\mathrm{Ct})$, defined as the fractional PCR cycle number at which fluorescence reaches 10 times the baseline SD, was used for comparison analysis. The $2^{-\Delta \Delta \mathrm{Ct}}$ method was used to evaluate the relative expression ratio for PDE10A compared with internal control gene $\beta$-actin. The following sequences of primers were used: PDE10A; forward, 5'-CCTCCACAACCAGTCCCATC-3'; reverse, 5' -CATCACCCTCAGCCCAGAA$3^{\prime} ; \beta$-actin: forward, 5'-GCGCAAGTACTCTGTGTGGA-3'; reverse, $5^{\prime}$-AAGGGTGTAAAACGCAGCT-3'.

Statistical evaluation. Data analysis was performed using the Statistical Package for the Social Sciences Windows, version 15.0 (SPSS). Descriptive statistics consisted of the mean \pm SD for parameters with Gaussian distributions (after confirmation with histograms and the Kolgomorov-Smirnov test). The homogeneity of the variance was evaluated by means of Levene's test. Comparison among groups was performed with the ANOVA followed by Bonferroni's test for multiple comparisons. $P$ value $<0.05$ was considered statistically significant.

\section{Results}

Nissl-stained sections

Nissl-stained sections showed various types of blue-stained neurons and glial cells through the rodent basal ganglia, whereas bundles of white matter were unstained. Qualitative assessment of Nissl staining and stereological analysis of total cell number in the caudate-putamen were compared among the three strains of animals ( $n=3$ animals per group). The blue staining pattern of neurons and glial cells in the caudate-putamen was similar among the three strains of animals (Fig. 1). Moreover, the total numbers of neurons and glial cells per unit test area $\left(1.35 \times 10^{5}\right.$ $\left.\mu \mathrm{m}^{2}\right)$ were comparable among the three strains $(462.7 \pm 32.18$ in NT, $489.7 \pm 39.55$ in hWT, and $497.2 \pm 30.48$ in hMT; df $=2$, $F=1.68, p=0.22$ ).
PDE10A immunohistochemistry in basal ganglia circuits

In control NT mice, intense PDE10A-like brown reaction product immunoreactivity was observed in numerous neuronal bodies and in the neuropil, both showing intense staining throughout the caudate-putamen (Figs. 2A, 3A). Intense PDE10A-like immunoreactivity was observed also in nerve fibers within the globus pallidus (Fig. $3 A, D$ ), the entopeduncular nucleus (Fig. $3 G$ ), and the substantia nigra pars reticulata (Fig. $4 A$ ). It is worth noting that, in NT mice, PDE10A immunoreactivity was comparable among the different brain areas, suggesting a balanced distribution of PDE10A in the striatum and its projection areas (Figs. 2A, 3A,D, G, 4A).

PDE10A immunoreactivity pattern changed in hWT mice and especially in hMT transgenic mice: in the caudate-putamen, PDE10A immunoreactivity appeared increased in some neurons, but decreased in other adjacent neurons and mainly in the surrounding neuropil (Fig. 2 B,C). Moreover, PDE10A immunoreactivity appeared increased in the globus pallidus of hWT and hMT (Fig. 3E,F) compared with NT mice, but decreased in the entopeduncular nucleus of hMT mice (Fig. 3I). It also decreased in the substantia nigra of hWT and hMT mice, compared with NT mice (Fig. $4 B, C$ ).

Densitometric analysis confirmed significant changes of PDE10A immunoreactivity in the basal ganglia among the three strains. In the caudate-putamen (Fig. 5), the PDE10A reaction product intensity was generally higher mainly in $\mathrm{hMT}$ mice and to a lesser extent in hWT mice, compared with NT mice $(\mathrm{df}=2, F=6.965, p<$ $0.05 \mathrm{NT}$ vs hWT and hMT).

In the globus pallidus (Fig. 5), PDE10A immunoreactivity was higher in hWT $(n=6)$ and hMT $(n=5)$ mice than in NT $(n=9)$ mice $(\mathrm{df}=2, F=24.894, p<0.01 \mathrm{NT}$ vs hWT and hMT).

Conversely, in the entopeduncular nucleus, PDE10A immunoreactivity was lower (Fig. 5$)$ in hMT $(n=5)$ than in NT $(n=9)$ mice $(\mathrm{df}=2, F=4.197, p<0.05 \mathrm{NT}$ vs hMT $)$. 

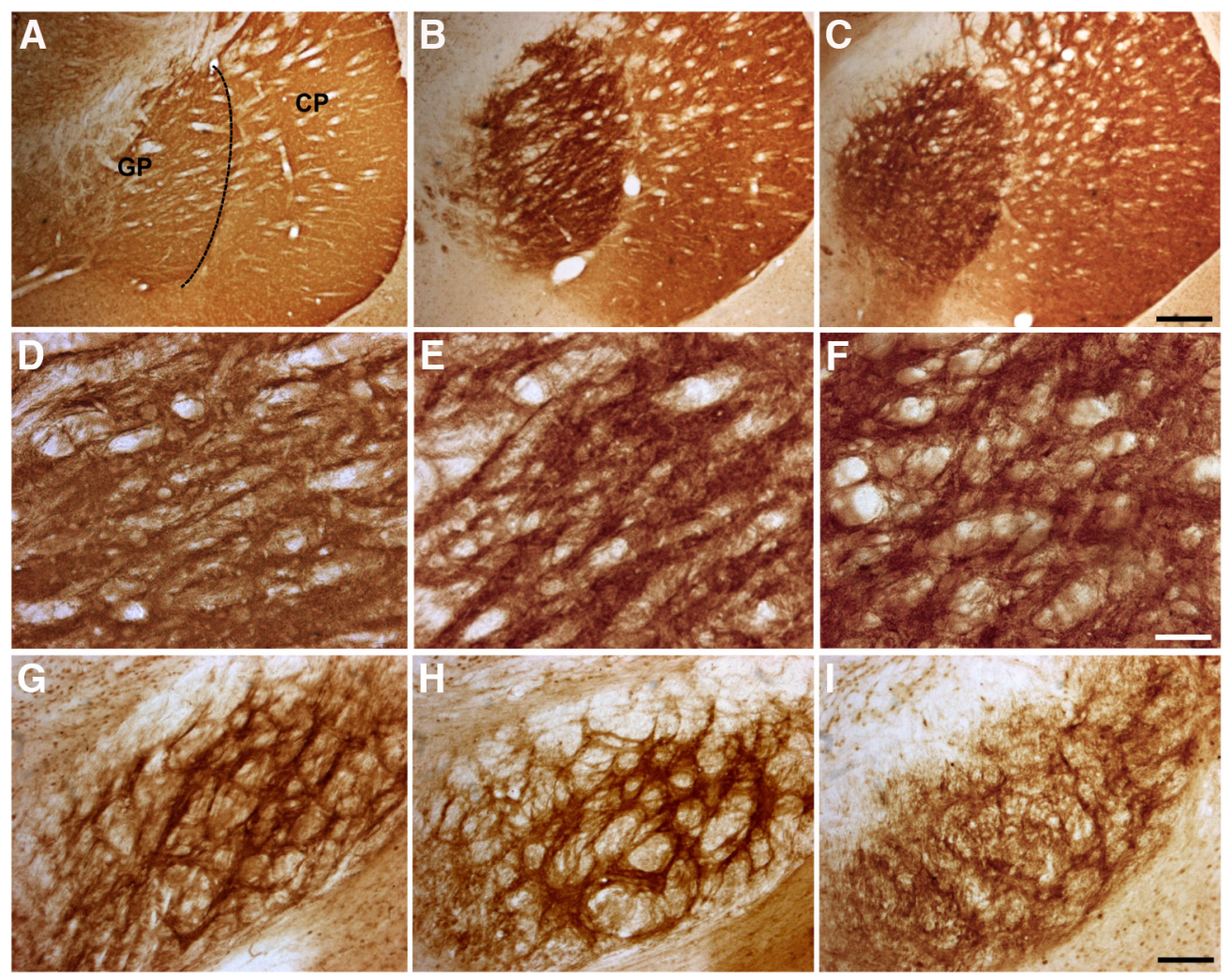

Figure 3. $A-I$, Microphotographs of PDE10A immunohistochemistry, comparing the brown reaction product intensity of the basal ganglia among $(\boldsymbol{A}, \boldsymbol{D}, \boldsymbol{G}) \mathrm{NT}$ mice, $(\boldsymbol{B}, \boldsymbol{E}, \boldsymbol{H}) \mathrm{hWT}$ mice, and $(\boldsymbol{C}$, $\boldsymbol{F}, \boldsymbol{I})$ hMT mice. Low-power microphotographs of the caudate-putamen (CP) and globus pallidus (GP) $(\boldsymbol{A}-\boldsymbol{C})$; plexus of PDE10A nerve fibers in the GP (D-F); plexus of PDE10A nerve fibers in the entopeduncular nucleus $(\mathbf{G}-\mathbf{I})$. Scale bars: $\boldsymbol{C}, 100 \mu \mathrm{m} ; \boldsymbol{F}, \mathbf{I}, 20 \mu \mathrm{m}$.
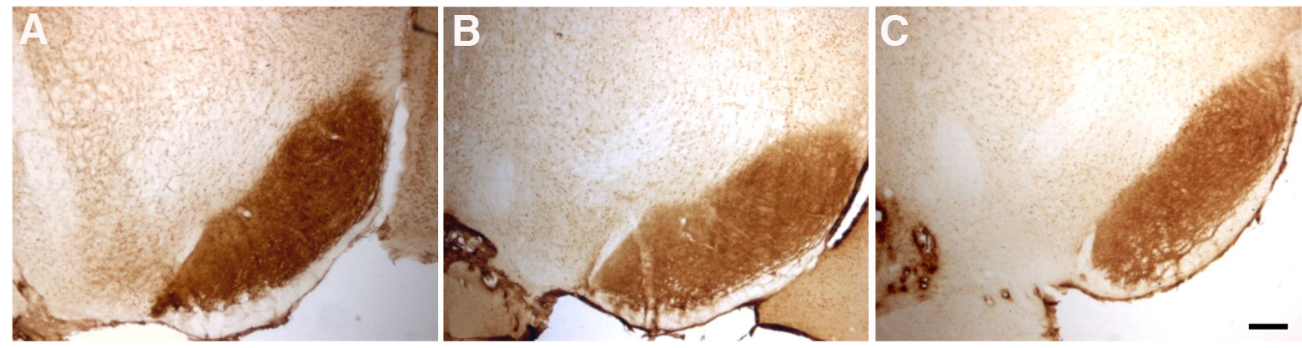

Figure 4. $\quad \boldsymbol{A}-\boldsymbol{C}$, Low-power microphotographs of PDE10A immunohistochemistry, comparing the brown reaction product intensity in the substantia nigra among NT mice $(\boldsymbol{A})$, hWT mice $(\boldsymbol{B})$, and hMT mice (C). Scale bar, $100 \mu \mathrm{m}$.

Moreover, PDE10A immunoreactivity was also lower in the substantia nigra pars reticulata (Fig. 5$)$ of both hMT $(n=5)$ and hWT $(n=6)$ compared with NT $(n=9)$ mice $(\mathrm{df}=2, F=$ $40.451, p<0.05$ NT vs hWT, $p<0.01$ NT vs hMT, and $p<0.01$ hWT vs hMT).

\section{PDE10A and Enk double immunofluorescence}

We hypothesized that the upregulation of PDE10A in striatal neurons of hMT mice would be selective for a subpopulation of neurons projecting to the external segment of the globus pallidus and likely containing Enk (Beckstead and Kersey, 1985).

In control NT mice, PDE10A immunofluorescence was observed in the vast majority of the striatal neurons, with similar intensity in the cell bodies and in the neuropil; however, individual neurons were characterized by a strong PDE10A immunofluorescence in the cytoplasm around the nucleus, which was invariably unstained (Fig. 6), as shown by Coskran et al. (2006).
Moreover, some neurons exhibited Enk-like immunofluorescence combined within the nucleus and the cytoplasm (Fig. 6), which is consistent with reports in rats, monkeys, and humans (McCollum et al., 2012). The morphological characteristics and distribution of Enk-positive cells in the striatum of NT and hMT mice ( $n=3$ mice in each group) were comparable (Fig. 6), as similarly reported in genetically dystonic hamsters (Kreil et al., 2011).

Colocalization of PDE10A and Enk in neurons of the dorsal striatum demonstrated that $100 \%$ of Enk-positive neurons were also PDE10A-positive, but only 36-39\% of PDE10A-positive neurons per microscopic field were labeled also for Enk both in NT and hMT mice. These data are consistent with the notion that virtually all PDE10A-positive neurons in the striatum are medium spiny projection neurons, but only approximately half of the medium spiny neurons are Enk-positive (Besson et al., 1990; Xie et al., 2006).

Surprisingly, in NT control animals, the content of PDE10A is different between the different neuronal subpopulations. Indeed, 


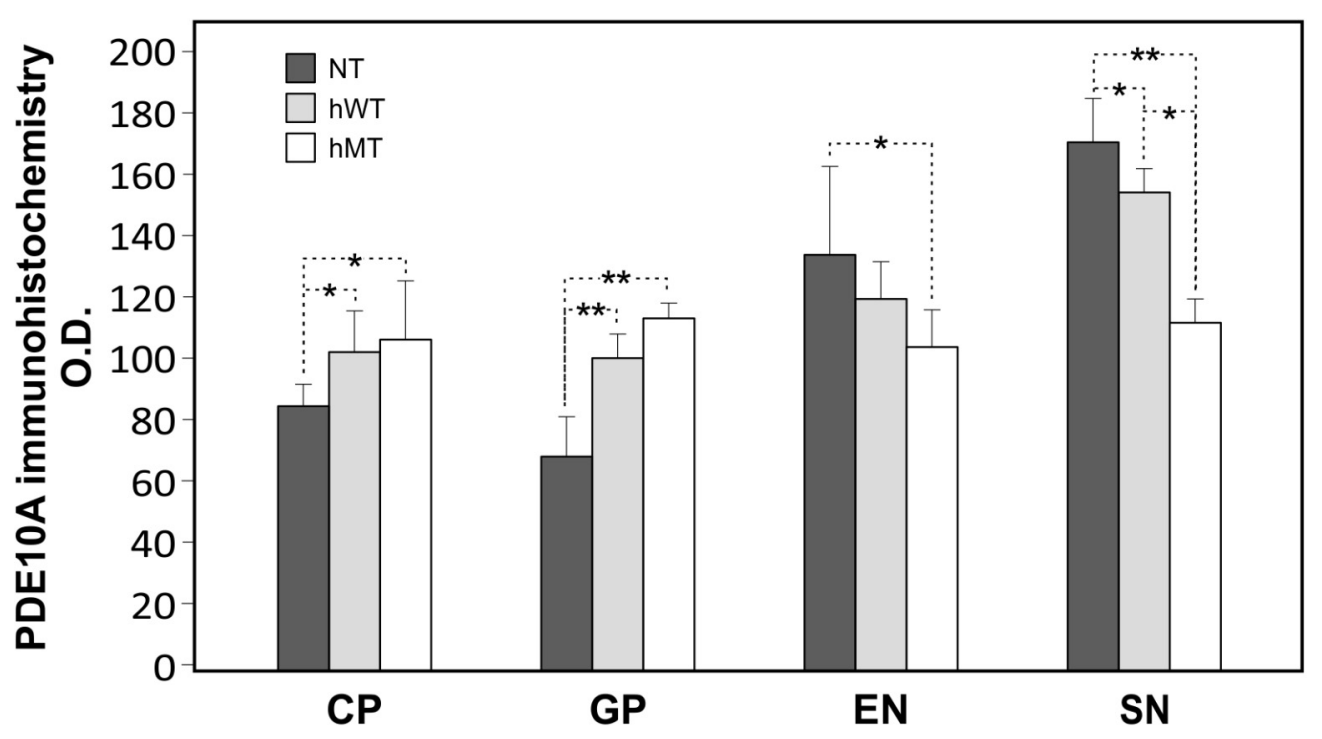

Figure 5. Comparative densitometric analysis of the PDE10A immunohistochemistry optical density (0.D.) per unit test area in different basal ganglia regions [caudate-putamen (CP), globus pallidus (GP), entopeduncular nucleus (EN), substantia nigra (SN)] of NT, hWT, and hMT mice. Values are expressed as means \pm SD of immunoreactive optical density per unit test area $\left(4.5 \times 10^{4}\right.$ $\left.\mu \mathrm{m}^{2}\right)$ in NT $(n=9)$, in hWT $(n=6)$, and in hMT $(n=5)$ mice. (P: $\mathrm{df}=2, F=6.965 ; \mathrm{GP}: \mathrm{df}=2, F=24.894$; EN: $\mathrm{df}=2, F=4.197 ; \mathrm{SN}$ : df $=2, F=40.451$. One-way ANOVA followed by Bonferroni's correction for multiple comparison. ${ }^{*} p<0.05,{ }^{* *} p<0.01$.

quantitative analysis of PDE10A per cell demonstrates that in NT striatal neurons the relative PDE10A immunofluorescence intensity was higher in Enk-negative compared with the Enk-positive neurons detected in the same microscopic fields ( $\mathrm{df}=1, F=$ 4.604, $p<0.05$; Fig. 7).

Furthermore, in hMT mice, the Enk-positive neurons displayed a selective increase of PDE10A immunofluorescence $(\mathrm{df}=$ $1, F=5.599, p<0.02$ ), whereas in the same microscopic fields the Enk-negative neurons had a slight nonsignificant PDE10A decrease, compared with the correspondent neuronal subpopulations in NT mice (Fig. 7). Therefore, the PDE10A content in Enk-positive neurons was as intense as in Enk-negative neurons of hMT mice, unlike the results in the NT mice (Fig. 7).

\section{PDE10A protein expression in basal ganglia circuits}

To evaluate further the relative intensity of PDE10A expression in the different groups of animals, Western blot analysis was performed using a specific polyclonal antibody on tissue extracts from different areas of the basal ganglia. In the three strains of animals, a single band of $88 \mathrm{Kda}$ PDE10A immunoreactivity was detected in tissue extracts from the different brain regions (Fig. 8), according to Seeger et al. (2003).

In NT control mice, PDE10A expression intensity was similar in the caudate-putamen, globus pallidus, and entopeduncular nucleus as per immunohistochemical results, but its intensity was higher in the substantia nigra pars reticulata (Figs. 5, 8). The higher content of PDE10A per milligram of protein in the substantia nigra could probably be due to the relatively more homogeneous anatomical distribution of the PDE10A content in this region (Fig. 4) than in the striatum, globus pallidus, and entopeduncular nucleus (Fig. 3), characterized instead by the intermingled distribution of gray and white matter.

In hWT $(n=6)$ and hMT $(n=6)$ mice, no significant differences in PDE10A expression were detected in the caudate-putamen compared with NT control mice $(n=6$; $\mathrm{df}=2, F=2.199$, $p>0.3 \mathrm{NT}$ vs hWT and hMT; Fig. 8). However, as seen in immunohistochemical results, hMT mice showed an increased PDE10A expression in the globus pallidus (Fig. 8), compared with NT and hWT mice $(\mathrm{df}=2, F=12.277, p<0.01 \mathrm{hMT}$ vs NT and hWT). Conversely, PDE10A expression in hMT mice was decreased in the entopeduncular nucleus $(\mathrm{df}=2, F=8.588, p<$ $0.01 \mathrm{NT}$ vs hMT), and in the substantia nigra ( $\mathrm{df}=2, F=4.399$, $p<0.05$ NT vs hMT; Fig. 8). Therefore, the significant differences between NT and hMT experimental groups detected by immunohistochemistry are confirmed by the quantitative Western blotting analysis in the globus pallidus, entopeduncular nucleus, and substantia nigra, demonstrating that data from Western blotting are precise and reliable in these areas but not in the caudate-putamen.

Moreover, PDE10A levels in the hWT mice are intermediate in expression between those of NT and hMT mice, as detected by immunohistochemistry and Western blotting in the different basal ganglia regions. However, the significant changes detected by immunohistochemistry in hWT mice compared with NT mice were not confirmed by the more variable values obtained by Western blotting analysis. This discrepancy would suggest that immunohistochemistry could be more sensitive than Western blotting to detect subtle changes in PDE10A. Indeed, immunohistochemistry can catch both membrane-bound and cytosol-soluble PDE10A isoforms in tissue (Charych et al., 2010), whereas in our experimental setting the Western blotting would preferentially detect cytosol-soluble PDE10A isoforms after extraction with low concentration of Triton X-100 $(0.1 \%)$. Future studies should evaluate possible selective changes between membrane-bound and cytosol-soluble PDE10A isoforms, differentiating PDE10A subcellular distribution in NT, hWT, and hMT mice.

\section{PDE and PDE10A activities}

We investigated whether changes in PDE10A expression in hMT mice and, to a lesser extent, in hWT mice consistently affected total cAMP-PDE activity and PDE10A-dependent cAMP hydrolyzing activity in tissue extracts. Total cAMP-PDE activity was evaluated as nmol cAMP hydrolyzed to inactive $5^{\prime} \mathrm{AMP} / \mathrm{min} / \mathrm{mg}$ protein. We used PDE10A selective inhibitor papaverine at a fixed concentration of $0.2 \mu \mathrm{M}$ (Siuciak et al., 2006; Giorgi et al., 2011) to evaluate PDE10A-dependent cAMP hydrolyzing activity 

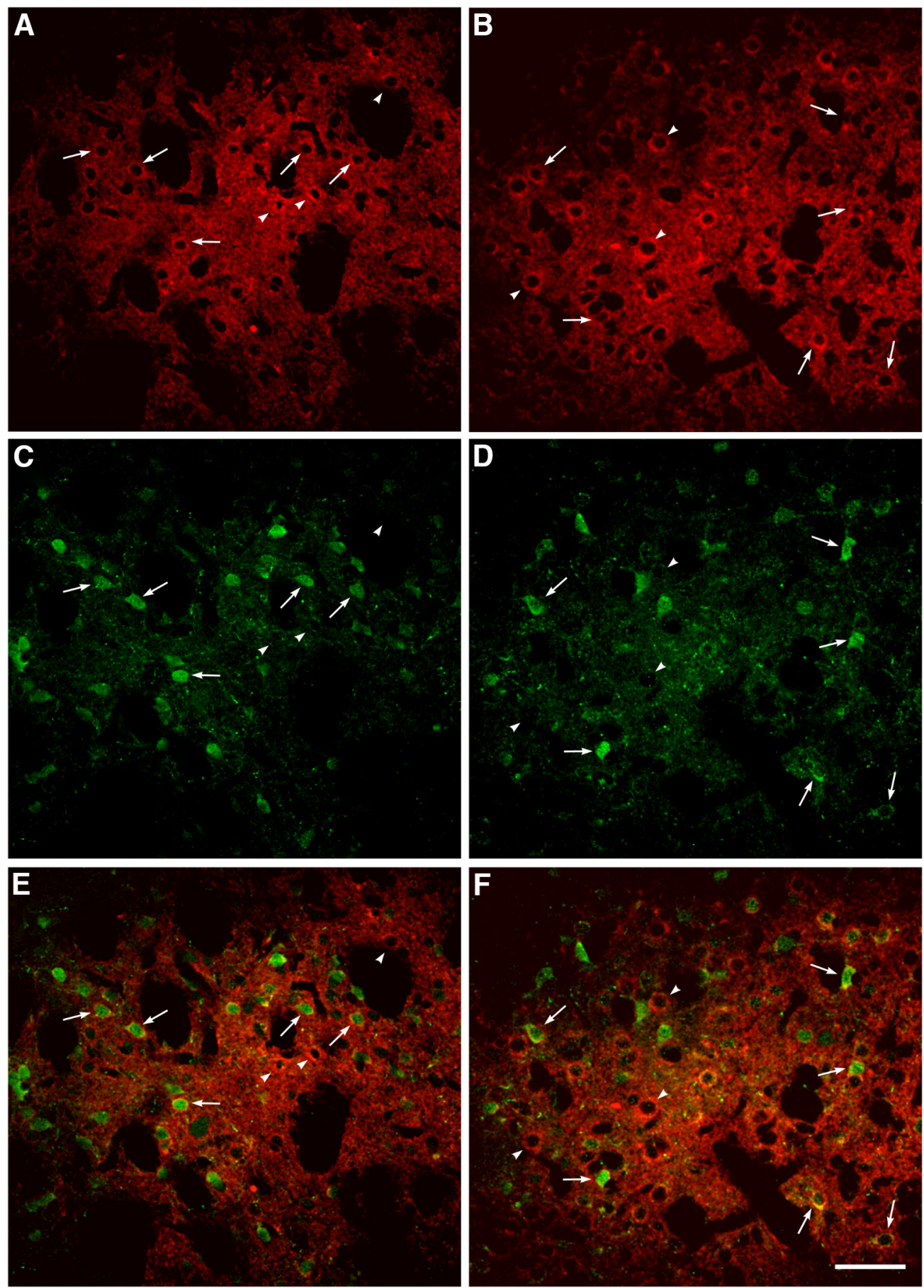

Figure 6. $A-F$, Confocal laser-scanning microscopy images of double-labeled immunofluorescence for PDE10A and Enk in NT $(\boldsymbol{A}, \boldsymbol{C}, \boldsymbol{E})$ and hMT $(\boldsymbol{B}, \boldsymbol{D}, \boldsymbol{F})$ mice. PDE10A immunolabeling is visualized by red-Cy3 fluorescence $(\boldsymbol{A}, \boldsymbol{B})$; Enk immunolabeling is visualized in green-Cy2 fluorescence $(\boldsymbol{C}, \boldsymbol{D})$; the merged images are shown in $\boldsymbol{E}$ and $\boldsymbol{F}$. The white arrows show some medium spiny projection neurons positive for both PDE10A and Enk, whereas white arrowheads point to some neurons positive for PDE10A, but negative for Enk. Scale bar, $50 \mu \mathrm{m}$.

in tissue extracts of different brain areas. The rate of papaverineinhibited PDE activity was assessed as the difference between the total and the papaverine-resistant PDE activity in each region of the different groups of animals.

\section{Total cAMP-PDE activity}

Total cAMP-PDE activity in tissue extracts from the caudateputamen was similar in the three strains ( $n=6$ in each group) of animals (Fig. 9; $\mathrm{df}=2, F=0.554, p>0.9 \mathrm{NT}$ vs hWT and hMT). However, total PDE activity was significantly increased in the globus pallidus of hMT mice $(\mathrm{df}=2, F=7.642, p<0.01 \mathrm{NT}$ vs
hMT), but significantly decreased in the entopeduncular nucleus of both hWT and hMT mice ( $\mathrm{df}=2, F=6.748, p<0.05 \mathrm{NT}$ vs hWT and hMT; Fig. 9). Moreover, a nonsignificant decrease of total cAMP-PDE activity was detected in the substantia nigra of both hWT and hMT mice ( $\mathrm{df}=2, F=0.772, p \geq 0.7 \mathrm{NT}$ vs hWT and hMT; Fig. 9).

\section{Papaverine-sensitive PDE activity}

According to the values of total PDE activity, the amount of papaverine-sensitive PDE activity ( $n=6$ in each group) in tissue extracts from the caudate-putamen was similar in the three strains of ani- 


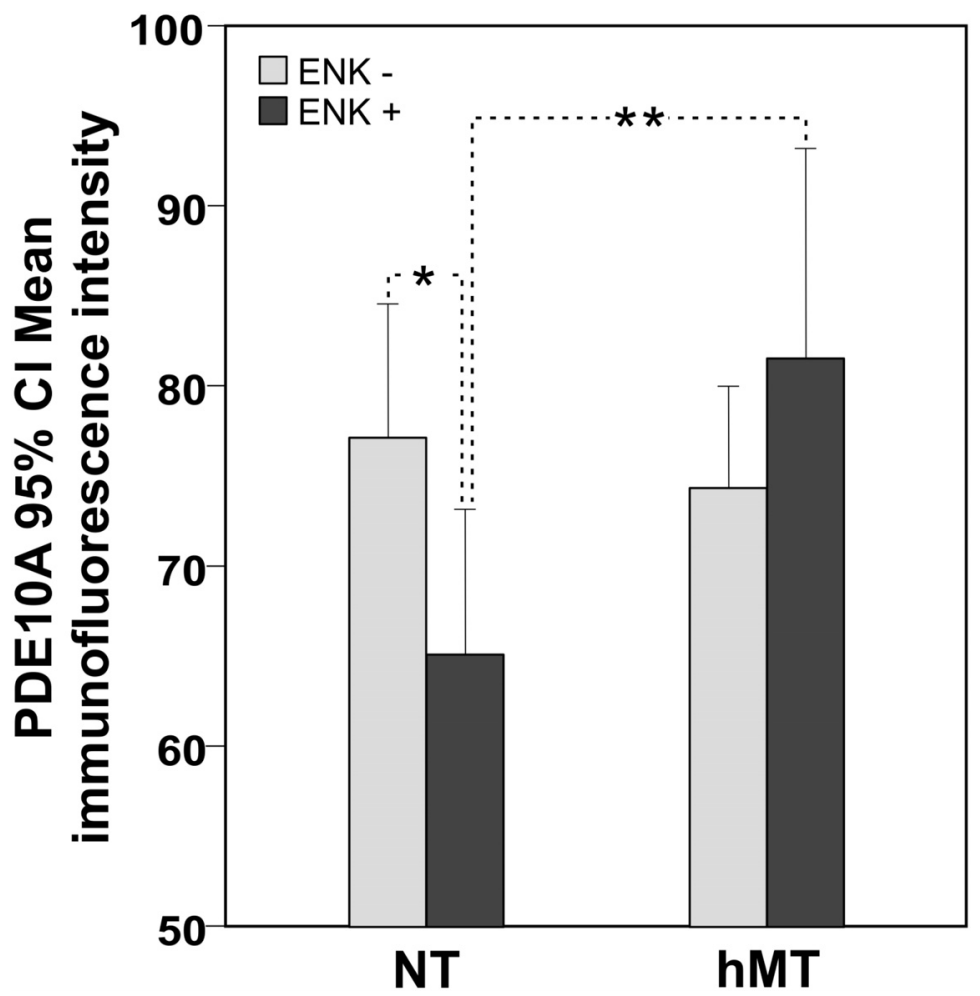

Figure 7. Comparative densitometric analysis of PDE10A immunofluorescence intensity colocalized in Enk-positive (ENK +) and Enk-negative (ENK - ) neurons of the dorsolateral striatum in NT and hMT mice. Results were expressed as the mean \pm SD of average gray values $(0-255)$ within the selected cells of the dorsolateral caudate-putamen of both hemispheres from three mice in each group. One-way ANOVA followed by Bonferroni's test for multiple comparisons. Comparisons within groups NT and hMT, and between groups NT $>$ hMT: ${ }^{*} p<0.05,{ }^{* *} p<0.02$.

mals. However, papaverine-sensitive PDE activity per milligram of protein was significantly increased in the globus pallidus of hMT (df $=2, F=8.794, p<0.01$ and $p<0.05$ hMT vs NT and hWT respectively; Table 1 ), but at the same time it was significantly decreased in the entopeduncular nucleus of hWT and hMT mice ( $\mathrm{df}=$ $2, F=5.325, p<0.05 \mathrm{NT}$ vs hWT and hMT; Table 1$)$. Instead, the amount of papaverine-sensitive cAMP-PDE activity in the substantia nigra was not significantly different for the three strains of animals $(\mathrm{df}=2, F=0.578, p>0.5$; Table 1$)$.

Therefore, the total cAMP-PDE activity and papaverinesensitive CAMP-PDE activity are either increased or decreased, respectively, in the globus pallidus and in the entopeduncular nucleus, consistent with the Western blot PDE10A expressions in the different basal ganglia areas in each group of animals. The inconsistent relationship between the significant decrease of PDE10A expression selectively expressed in the substantia nigra pars reticulata and the highly variable nonsignificant changes in the total and papaverine-inhibited cAMP-PDE activity is probably due to the interference of other PDE isoforms in the surrounding structures (Lakics et al., 2010). These, indeed, cannot easily be dissected from the substantia nigra pars reticulata because of the small size and anatomical complexity of the region.

\section{Papaverine-resistant cAMP-PDE activity}

To evaluate further the contribution of PDE10A to the total PDE activity, we compared the values of papaverine-resistant cAMPPDE activity in the different basal ganglia structures. The relationship between total PDE activity and papaverine-resistant PDE activity was highly significant in the caudate-putamen (Fig. 9) for the three strains of animals ( $\mathrm{df}=5, F=25.958, p<0.01$ total PDE vs papaverine-resistant PDE), suggesting that the con- tribution of PDE10A per milligram of protein is higher in the caudate-putamen than in the globus pallidus and the entopeduncular nucleus. Moreover, a significant relationship between total PDE activity and papaverine-resistant PDE activity was observed only in the hMT globus pallidus $(\mathrm{df}=5, F=8.984, p<0.01)$, but not in the entopeduncular nucleus (df $=5, F=6.377, p \geq 0.5$ ) and in the substantia nigra $(\mathrm{df}=5, F=2.309, p>$ $0.6)$. It is noteworthy, instead, that the amount of papaverine-resistant cAMPPDE activity is similar in the caudate-putamen (Fig. 9) for the three strains of animals, but it was significantly lower in the entopeduncular nucleus of hWT and hMT mice compared with NT mice $(\mathrm{df}=$ 2, $F=6.875, p<0.05 \mathrm{NT}$ vs hWT and hMT; Fig. 9). These data suggest that the increase and decrease of total PDE activity in the globus pallidus and entopeduncular nucleus, respectively, are likely due to the concordant changes of PDE10A activity in the same structures.

\section{PDE10A mRNA}

RT-PCR amplification of PDE10A mRNA was performed in the different groups of animals to investigate PDE10A changes at the transcriptional level in basal ganglia. The primers, which amplified a specific mRNA fragment (140 bp), gave a strong PDE10A signal in the caudate-putamen of NT mice $(n=5$; Fig. $10 A)$. However, in agreement with the results of Seeger et al. (2003), PDE10A mRNA was not detected at all, or just in low amounts, in the globus pallidus, entopeduncular nucleus, and substantia nigra (Fig. 10B). The pattern and relative intensity of PDE10A mRNA expression detected in the caudate-putamen of NT mice were similar in the caudate-putamen of both hWT and hMT mice (Fig. 10A).

\section{Discussion}

The main findings of our work are the differential changes to PDE10A that occur in the striatal neurons' subpopulations of hMT mice, associated with increased or decreased PDE10A expression and activity respectively in the globus pallidus and in the entopeduncular nucleus/substantia nigra.

It is noteworthy that changes to PDE10A occur also in basal ganglia circuits of hWT mice, but to a lesser extent than in hMT mice. Our data are in agreement with the work of Grundmann et al. (2007), which showed that neuropathological, neurochemical, and behavioral abnormalities occur not only in hMT mice, but also in hWT mice. However, the most significant PDE10A changes are observed in hMT mice, suggesting that mutant tor$\sin \mathrm{A}$ can have more severe consequences on neuronal dysfunctions than hyperexpression of wild-type torsinA.

Such changes to PDE10A in the indirect and direct pathways are specific to hMT mice; experimental parkinsonism in rat is indeed characterized by decreased PDE10A protein levels and activity in striatal neurons as well as in striatopallidal and striatonigral projections (Giorgi et al., 2011). 


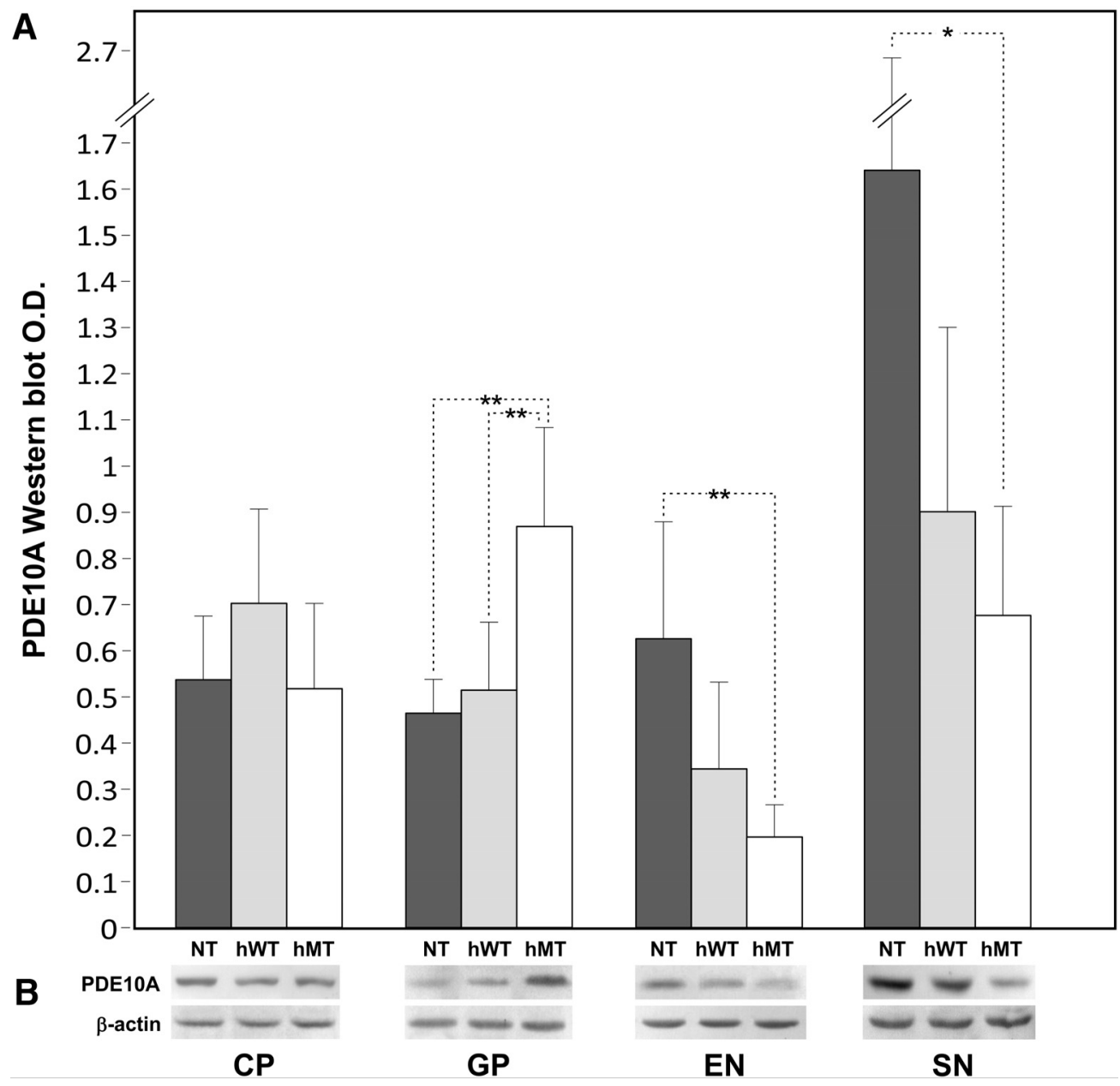

Figure 8. A, Comparative densitometry optical density (0.D.) of PDE10A Western blotting bands in correspondent areas of the basal ganglia of NT, hWT, and hMT mice. Results were expressed as the mean $\pm S D$ of values obtained from both hemispheres from six mice in each group. (P, caudate-putamen ( $\mathrm{df}=2, F=2.199) ; \mathrm{GP}$, globus pallidus (df $=2, F=12.277$ ); $\mathrm{EN}$, entopeduncular nucleus ( $\mathrm{df}=2, F=8.588$ ); $\mathrm{SN}$, substantia nigra ( $\mathrm{df}=2, F=4.399$ ). One-way ANOVA followed by Bonferroni's test for multiple comparisons. ${ }^{*} p<0.05,{ }^{* *} p<0.01 . \boldsymbol{B}$, Representative immunoblots of PDE10A protein content in the CP, GP, EP, and SN of NT, hWT, and hMT mice. $\beta$-Actin was used as the internal reference standard.

\section{PDE10A expression patterns in the caudate-putamen neurons}

We investigated whether the upregulation and downregulation of PDE10A immunoreactivity among the striatal neurons would be selective for the striatopallidal and striatoentopeduncular/nigral neurons of hMT mice, containing respectively Enk or substance P (Beckstead and Kersey, 1985). This study has some limitations that must be pointed out.

The immunohistochemistry of substance $\mathrm{P}$ striatal projection neurons was not included in this study because a reliable immunostaining of substance P-positive perikaria was difficult to achieve in mice (data not shown) without intraventricular colchicine pretreatment, which blocks the axonal transport (Beckstead and Kersey, 1985; Reiner et al., 1988). Therefore, the PDE10A-positive/Enk-negative neurons were presumably identified as the striatoentopeduncular/nigral projection neurons.

Our data demonstrate that the increased PDE10A immunoreactivity in striatal neurons of hMT mice is expressed only in Enk-positive striatal neurons, displaying concordant PDE10A increase in the projections to the globus pallidus.

Conversely, densitometry analysis in Enk-negative neurons of hMT mice did not show significant changes in PDE10A immunoreactivity within the neuronal bodies throughout the dorsolateral striatum, even though their presumed projections to the entopeduncular nucleus and substantia nigra display reduced PDE10A expression and activity compared with those of NT mice. Therefore, we cannot link with certainty the reduction of PDE10A in striatoentopeduncular-nigral projections of hMT mice to concordant PDE10A changes in the neuronal body of Enk-negative striatal neurons.

However, we note that qualitative analysis of PDE10A immunohistochemical staining in the striatum reveals reduced immunoreaction product mainly in the neuropil of hMT mice. Instead, densitometry analysis of PDE10A fluorescence evaluated by using the Java image processing is technically focused on the neuronal bodies, the area where PDE10A immunoreaction can be attributed with some certainty either to Enk-positive or Enknegative neurons. Therefore, selective changes of PDE10 in the neuropil of a specific neuronal subpopulation could be missed in immunofluorescence analysis.

Moreover, unlike the differentiated immunohistochemical data collected in neuronal subpopulations of the caudate-putamen, PDE10A expression and activity were similar in the caudate-putamen homogenates among the three strains of mice. The difference between morphological and biochemical data in the striatum could be explained by the observation that tissue homogenates cannot detect the differentiated changes between neuropil and neuronal bodies present in the same areas. There- 


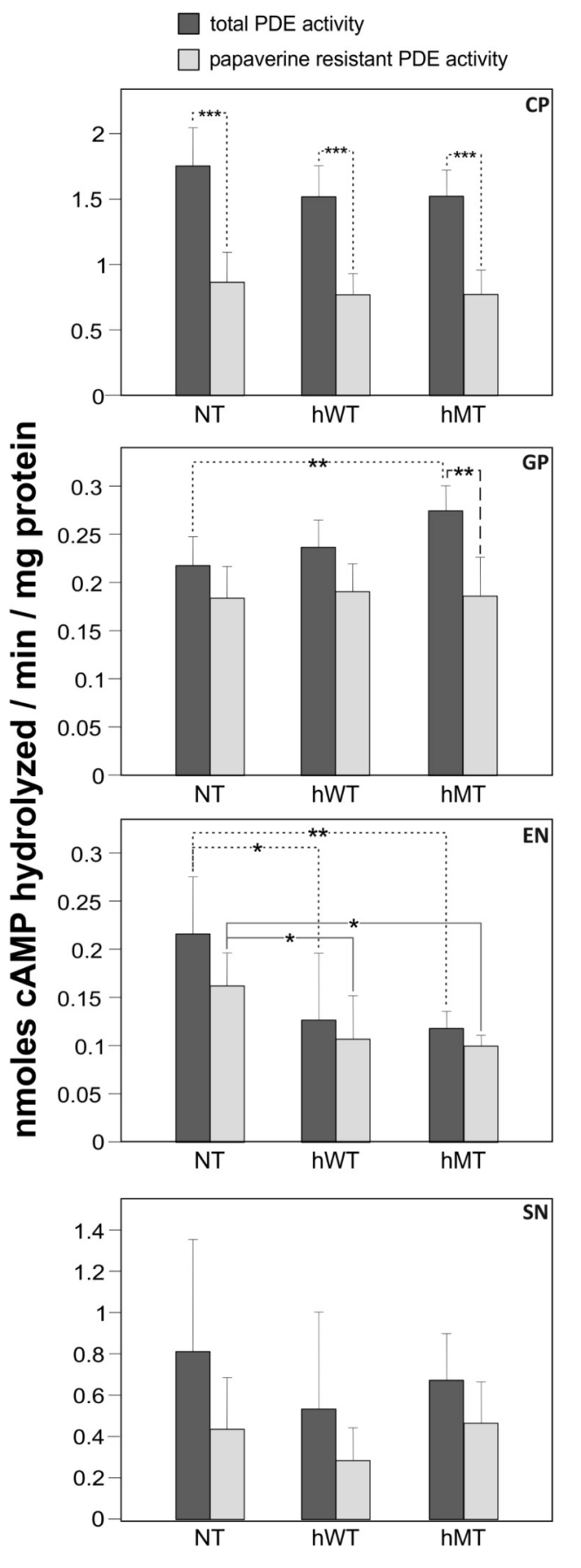

Figure 9. Total PDE activity (dark gray columns) and papaverine-resistant PDE activity (light gray columns) in the caudate-putamen (CP), globus pallidus (GP), entopeduncular nucleus (EN), and substantia nigra (SN) of NT, hWT, and hMT mice; $n=6$ in each group. A fixed papaverine concentration $(0.2 \mu \mathrm{M})$ was used to allow comparison of the papaverine-resistant PDE activity between the correspondent brain regions in the different experimental groups. Values are expressed as nmol cAMP hydrolyzed/min/mg proteins $\pm \mathrm{SD} . \mathrm{CP}: \mathrm{df}=2, F=0.554$; $\mathrm{GP}: \mathrm{df}=2, F=7.642 ; \mathrm{EN}, \mathrm{df}=2, F=6.748 ; \mathrm{SN}: \mathrm{df}=2, F=0.772$. One-way ANOVA followed by Bonferroni's correction for multiple data. $\left(\mathrm{P}:{ }^{* *} p<0.01\right.$ total versus papaverine-resistant PDE activity in each group. GP: ${ }^{* *} p<0.01$ total PDE activity in NT versus hMT; ${ }^{* *} p<0.01$ total versus papaverine-resistant PDE activity in hMT group. EN: ${ }^{*} p<0.05$ NT versus hWT, and ${ }^{* *} p<0.01$ NT versus hMT. SN: $p>0.6$ NT versus hWT and hMT.

fore, the subcellular distribution of PDE10A should be further investigated to fully document PDE10A changes in neuronal bodies, dendrites, and terminals of Enk-negative and Enkpositive neurons in hMT mice.
Table 1. Papaverine-inhibited PDE activity in different regions of the basal ganglia in NT, hWT, and hMT mice

\begin{tabular}{llll}
\hline Brain region & NT & hWT & hMT \\
\hline Caudate-putamen & $0.878 \pm 0.136$ & $0.743 \pm 0.179$ & $0.755 \pm 0.141$ \\
Globus pallidus & $0.034 \pm 0.014$ & $0.046 \pm 0.016^{*}$ & $0.088 \pm 0.035^{* *}$ \\
Entopeduncular nucleus & $0.054 \pm 0.026$ & $0.028 \pm 0.009^{*}$ & $0.020 \pm 0.013^{*}$ \\
Substantia nigra & $0.37 \pm 0.28$ & $0.26 \pm 0.11$ & $0.22 \pm 0.17$ \\
\hline
\end{tabular}

Total PDE activity was assayed in the presence of $0.1 \mu \mathrm{M}$ cAMP; papaverine-inhibited PDE activity was evaluated after adding a fixed dose of papaverine $(0.2 \mu \mathrm{M})$. PDE activity was detected as nmol cAMP hydrolyzed/min $/ \mathrm{mg}$ protein. Papaverine-inhibited PDE activity was calculated as the difference between the basal PDE activity and the residual PDE activity assayed in the presence of papaverine. $N=6$ in each group. One-way ANOVA followed by Bonferroni's correction for multiple data. Caudate-putamen: no significant differences between NT, hWT, and hMT mice; globus pallidus: ${ }^{* *} p<0.01$ NT versus $h M T,{ }^{*} p<0.05$ hWT versus $h M T$; entopeduncular nucleus: ${ }^{*} p<0.05$ NT versus hWT, and versus hMT; substantia nigra: no significant differences between NT, hWT, and hMT mice.

Finally, we have demonstrated that the PDE10A mRNA expression was similar in the three strains, suggesting that the changes of PDE10A expression and activity in hWT and hMT mice occur at the post-transcriptional level. Therefore, the neurochemical relationship between the mutant torsinA protein and the different changes of PDE10A in Enk-positive and in Enknegative neurons is unknown. One should consider the possibility that mutant torsin A protein in hMT mice determines variable expression of PDE10A in striatal circuits in the context of a mosaic of abnormal striatal plasticity (Quartarone and Pisani, 2011).

\section{Role of PDE10A upregulation and downregulation in striatal} projection neurons

In previous work we demonstrated that the cAMP levels are either increased or decreased in a rat experimental model of parkinsonism according to the downregulation or upregulation of PDE10A expression and activity, respectively, in neurons of the caudate-putamen and nucleus accumbens (Giorgi et al., 2011). The inverse changes to PDE10A in the striatal indirect and direct pathways of hMT mice can affect the rate of catabolism of second messenger cAMP and cGMP, differentially modulating the functions of basal ganglia circuits, not only in the striatum but also in its projection areas (Threlfell et al., 2009; Threlfell and West, 2013; Padovan-Neto et al., 2015). Several studies indicate the importance of presynaptic cAMP signaling/degradation in the control of striatonigral and striatopallidal projections and in other areas. Indeed, the modulation of neural transmission can occur also at synaptic terminals independent of the propagation of action potentials triggered by excitation of cell bodies to the terminals (Shindou et al., 2002; Fourcaudot et al., 2008; Mango et al., 2014).

The cAMP synthesis in striatal neurons is stimulated by dopamine D1 receptors, mainly expressed in the GABAergic projection neurons of the direct pathway, and by adenosine A2A receptors, mainly expressed in the GABAergic projection neurons of the indirect pathway (Cooper, 2003; Schiffmann et al., 2007). In addition, dopamine D2 receptors, mainly expressed in the GABAergic projection neurons of the indirect pathway (Querejeta et al., 2001; Cooper, 2003), inhibit cAMP synthesis and tightly interact structurally and functionally with the A2A receptors, exhibiting reciprocal antagonistic interactions (Ferré et al., 1997; Salmi et al., 2005). Furthermore, the dopamine D1 and D2 receptors also stimulate or inhibit cGMP synthesis, respectively (Cooper, 2003; Sammut et al., 2006, 2007). Therefore, functional relevance of the inverse PDE10A changes in hMT mice could be unraveled in the context of the complexity of basal ganglia circuits and of D1, A2A, and D2 interactions.

Actually, PDE10A, by hydrolyzing cAMP, can regulate the amplitude and the duration of CAMP/PKA signaling stimulated 

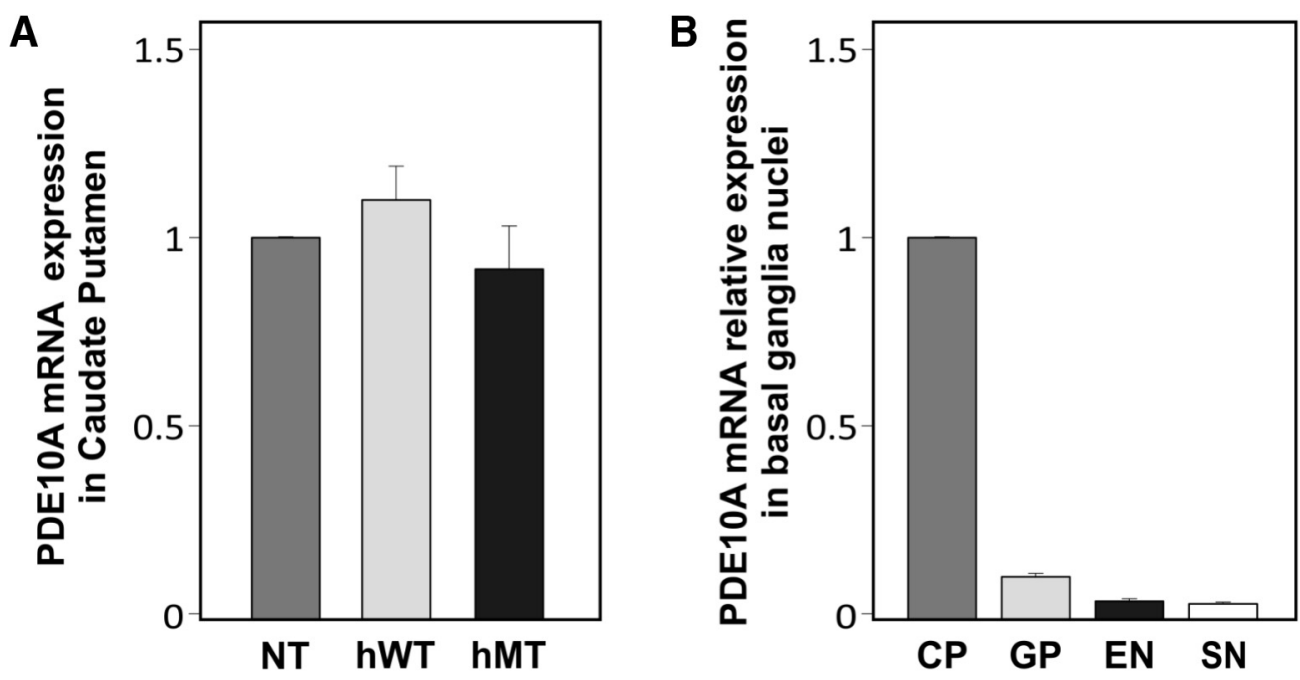

Figure 10. A, Comparative real-time PCR of PDE10A mRNA in caudate-putamen of NT, hWT, and hMT mice. The expression of PDE10A mRNA in hWT mice and in hMT mice is compared to the levels in NT mice. One-way ANOVA followed by Bonferroni's correction for multiple data. $B$, Comparative real-time PCR of PDE10A mRNA in basal ganglia nuclei of NT mice. CP, caudate-putamen; GP, globus pallidus; EN, entopeduncular nucleus; $S N$, substantia nigra. Results were expressed as the mean \pm SD of values obtained from six mice in each group.

by dopamine D1 receptors, finally leading to the inhibition of the D1-dependent stimulator signaling in the direct striatoentopeduncular neurons (Nishi et al., 2008). Moreover, PDE10A also can limit the amplitude and the duration of the CAMP/PKA signaling stimulated by adenosine $\mathrm{A} 2 \mathrm{~A}$, finally leading to the potentiation of dopamine D2 inhibitor signaling in the indirect striatopallidal neurons (Nishi et al., 2008). In addition, PDE10A activity can modulate amplitude and duration of cGMP signals in the striatum, either stimulated by D1 or downregulated via D2 receptor-dependent mechanisms, limiting excitatory corticostriatal transmission (Padovan-Neto et al., 2015).

Our observations that PDE10A expression is downregulated in the direct striatoentopeduncular/substantia nigra pathway of hMT mice suggest that amplitude and duration of cAMP/cGMP signals (induced by D1 receptors) are increased because of reduced PDE10A activity, at least in the striatonigral and striatoentopeduncular terminals. On the other hand, the PDE10A upregulation in the indirect striatopallidal pathway of hMT mice suggests that amplitude and duration of cAMP signals (stimulated by adenosine $\mathrm{A} 2 \mathrm{~A}$ receptors) are reduced because of increased PDE10A activity, both in the neuronal bodies and in their projections, thus potentiating D2 receptor-mediated inhibition of cAMP/cGMP signals.

Therefore, the inverse changes of PDE10A in striatoentopeduncular and striatopallidal pathway of hMT mice may affect at a given time the functions of the D1 and D2 receptors, determining an increase in amplitude and duration of cAMP/cGMPstimulated or cAMP/cGMP-inhibited signals in the direct and indirect pathways, respectively. Our results reflect a recently proposed model of dysfunction of basal ganglia circuits, suggesting that changes in both indirect and direct pathways would disrupt functions in the basal ganglia-thalamus-cortex motor circuit and ultimately the ability to focus movements properly (Hendrix and Vitek, 2012).

Previous experimental evidence from animal models of dystonia indicates a crucial role for striatal cholinergic interneurons in the pathophysiology of dystonia (Pisani et al., 2006; Sciamanna et al., 2009, 2011, 2012). Moreover, electrophysiological data in hMT mice demonstrate a disinhibition of striatal GABAergic synaptic activity that can be partially attributed to a D2 dopamine receptor dysfunction (Sciamanna et al., 2009). Interestingly, the impairment of D2 receptor-dependent synaptic plasticity, observed in hMT mice, was fully restored by pharmacological blockade of adenosine A2A receptors (Napolitano et al., 2010), raising the question as to whether PDE10A upregulation in striatopallidal projections of hMT mice could be a compensatory mechanism to altered reciprocal antagonistic interactions between adenosine A2A and dopamine D2 receptors. Furthermore, DYT1 transgenic mice exhibit significantly decreased striatal D1 receptor binding activity and protein levels, suggesting that along with the D2 indirect pathway, the direct pathway is also affected (Yokoi et al., 2015).

In conclusion, our study demonstrates opposing PDE10A changes in the striatopallidal and striatoentopeduncular connections, suggesting a widespread involvement of striatal neuronal subtypes in the pathophysiology of dystonia. The inverse changes of PDE10A in basal ganglia circuits of hMT mice can determine at a given time an increased intensity and duration of both D1 receptorstimulated and D2 receptor-inhibited cAMP/PKA and cGMP signaling cascades, respectively, in the direct and indirect pathways.

\section{References}

Ahmad R, Bourgeois S, Postnov A, Schmidt ME, Bormans G, Van Laere K, Vandenberghe W (2014) PET imaging shows loss of striatal PDE10A in patients with Huntington disease. Neurology 82:279-281. CrossRef Medline

Albanese A, Bhatia K, Bressman SB, Delong MR, Fahn S, Fung VS, Hallett M, Jankovic J, Jinnah HA, Klein C, Lang AE, Mink JW, Teller JK (2013) Phenomenology and classification of dystonia: a consensus update. Mov Disord 28:863-873. CrossRef Medline

Albin RL, Young AB, Penney JB (1989) The functional anatomy of basal ganglia disorders. Trends Neurosci 12:366-375. CrossRef Medline

Alexander GE, Crutcher MD (1990) Functional architecture of basal ganglia circuits: neural substrates of parallel processing. Trends Neurosci 13:266271. CrossRef Medline

Augood SJ, Keller-McGandy CE, Siriani A, Hewett J, Ramesh V, Sapp E, DiFiglia M, Breakefield XO, Standaert DG (2003) Distribution and ultrastructural localization of torsinA immunoreactivity in the human brain. Brain Res 986:12-21. CrossRef Medline

Beckstead RM, Kersey KS (1985) Immunohistochemical demonstration of differential substance P-, met-enkephalin-, and glutamic-aciddecarboxylasecontaining cell body and axon distributions in the corpus striatum of the cat. J Comp Neurol 232:481-498. CrossRef Medline 
Besson MJ, Graybiel AM, Quinn B (1990) Co-expression of neuropeptides in the cat's striatum: an immunohistochemical study of substance $P$, dynorphin B and enkephalin. Neuroscience 39:33-58. CrossRef Medline

Charych EI, Jiang LX, Lo F, Sullivan K, Brandon NJ (2010) Interplay of palmitoylation and phosphorylation in the trafficking and localization of phosphodiesterase 10A: implications for the treatment of schizophrenia. J Neurosci 30:9027-9037. CrossRef Medline

Cooper DM (2003) Molecular and cellular requirements for the regulation of adenylate cyclases by calcium. Biochem Soc Trans 31:912-915. CrossRef Medline

Coskran TM, Morton D, Menniti FS, Adamowicz WO, Kleiman RJ, Ryan AM, Strick CA, Schmidt CJ, Stephenson DT (2006) Immunohistochemical localization of phosphodiesterase 10A in multiple mammalian species. J Histochem Cytochem 54:1205-1213. CrossRef Medline

Defazio G, Berardelli A, Hallett M (2007) Do primary adult-onset focal dystonias share aetiological factors? Brain 130:1183-1193. CrossRef Medline

DeLong MR (1990) Primate models of movement disorders of basal ganglia origin. Trends Neurosci 13:281-285. CrossRef Medline

Fahn S, Bressman SB, Marsden CD (1998) Classification of dystonia. Adv Neurol 78:1-10. Medline

Ferré S, Fredholm BB, Morelli M, Popoli P, Fuxe K (1997) Adenosine-dopamine receptor-receptor interactions as an integrative mechanism in the basal ganglia. Trends Neurosci 20:482-487. CrossRef Medline

Fourcaudot E, Gambino F, Humeau Y, Casassus G, Shaban H, Poulain B, Lüthi A (2008) cAMP/PKA signaling and RIMlalpha mediate presynaptic LTP in the lateral amygdala. Proc Natl Acad Sci U S A 105:1513015135. CrossRef Medline

Giorgi M, D’Angelo V, Esposito Z, Nuccetelli V, Sorge R, Martorana A, Stefani A, Bernardi G, Sancesario G (2008) Lowered cAMP and cGMP signalling in the brain during levodopa-induced dyskinesias in hemiparkinsonian rats: new aspects in the pathogenetic mechanisms. Eur J Neurosci 28:941-950. CrossRef Medline

Giorgi M, Melchiorri G, Nuccetelli V, D’Angelo V, Martorana A, Sorge R, Castelli V, Bernardi G, Sancesario G (2011) PDE10A and PDE10Adependent cAMP catabolism are dysregulated oppositely in striatum and nucleus accumbens after lesion of midbrain dopamine neurons in rat: a key step in parkinsonism physiopathology. Neurobiol Dis 43:293-303. CrossRef Medline

Goodchild RE, Grundmann K, Pisani A (2013) New genetic insights highlight 'old' ideas on motor dysfunction in dystonia. Trends Neurosci 36: 717-725. CrossRef Medline

Grundmann K, Reischmann B, Vanhoutte G, Hübener J, Teismann P, Hauser TK, Bonin M, Wilbertz J, Horn S, Nguyen HP, Kuhn M, Chanarat S, Wolburg H, Van der Linden A, Riess O (2007) Over-expression of human wildtype torsinA and human DeltaGAG torsinA in a transgenic mouse model causes phenotypic abnormalities. Neurobiol Dis 27:190206. CrossRef Medline

Hebb AL, Robertson HA, Denovan-Wright EM (2004) Striatal phosphodiesterase mRNA and protein levels are reduced in Huntington's disease transgenic mice prior to the onset of motor symptoms. Neuroscience 123:967-981. CrossRef Medline

Hendrix CM, Vitek JL (2012) Toward a network model of dystonia. Ann N Y Acad Sci 1265:46-55. CrossRef Medline

Kanovský P (2002) Dystonia: a disorder of motor programming or motor execution? Mov Disord 17:1143-1147. CrossRef Medline

Kreil A, Hamann M, Sander SE, Richter A (2011) Changes in dynorphin immunoreactivity but unaltered density of enkephalin immunoreactive nerons in basal ganglia nuclei of genetically dystonic hamsters. Synapse 65:1196-1203. CrossRef Medline

Lakics V, Karran EH, Boess FG (2010) Quantitative comparison of phosphodiesterase mRNA distribution in human brain and peripheral tissues. Neuropharmacology 59:367-374. CrossRef Medline

Leuti A, Laurenti D, Giampà C, Montagna E, Dato C, Anzilotti S, Melone MA, Bernardi G, Fusco FR (2013) Phosphodiesterase 10A (PDE10A) localization in the R6/2 mouse model of Huntington's disease. Neurobiol Dis 52:104-116. CrossRef Medline

Mango D, Bonito-Oliva A, Ledonne A, Nisticò R, Castelli V, Giorgi M, Sancesario G, Fisone G, Berretta N, Mercuri NB (2014) Phosphodiesterase $10 \mathrm{~A}$ controls D1-mediated facilitation of GABA release from striatonigral projections under normal and dopamine-depleted conditions. Neuropharmacology 76:127-136. CrossRef Medline
Martella G, Tassone A, Sciamanna G, Platania P, Cuomo D, Viscomi MT, Bonsi P, Cacci E, Biagioni S, Usiello A, Bernardi G, Sharma N, Standaert DG, Pisani A (2009) Impairment of bidirectional synaptic plasticity in the striatum of a mouse model of DYT1 dystonia: role of endogenous acetylcholine. Brain 132:2336-2349. CrossRef Medline

McCollum LA, Roche JK, Roberts RC (2012) Immunohistochemical localization of enkephalin in the human striatum: a postmortem ultrastructural study. Synapse 66:204-219. CrossRef Medline

Napolitano F, Pasqualetti M, Usiello A, Santini E, Pacini G, Sciamanna G, Errico F, Tassone A, Di Dato V, Martella G, Cuomo D, Fisone G, Bernardi G, Mandolesi G, Mercuri NB, Standaert DG, Pisani A (2010) Dopamine D2 receptor dysfunction is rescued by adenosine A2A receptor antagonism in a model of DYT1 dystonia. Neurobiol Dis 38:434-445. CrossRef Medline

Niccolini F, Foltynie T, Reis Marques T, Muhlert N, Tziortzi AC, Searle GE, Natesan S, Kapur S, Rabiner EA, Gunn RN, Piccini P, Politis M (2015a) Loss of phosphodiesterase 10A expression is associated with progression and severity in Parkinson's disease. Brain 138:3003-3015. CrossRef Medline

Niccolini F, Haider S, Reis Marques T, Muhlert N, Tziortzi AC, Searle GE, Natesan S, Piccini P, Kapur S, Rabiner EA, Gunn RN, Tabrizi SJ, Politis M (2015b) Altered PDE10A expression detectable early before symptomatic onset in Huntington's disease. Brain 138:3016-3029. CrossRef Medline

Nishi A, Kuroiwa M, Miller DB, O'Callaghan JP, Bateup HS, Shuto T, Sotogaku N, Fukuda T, Heintz N, Greengard P, Snyder GL (2008) Distinct roles of PDE4 and PDE10A in the regulation of CAMP/PKA signaling in the striatum. J Neurosci 28:10460-10471. CrossRef Medline

Ozelius LJ, Hewett JW, Page CE, Bressman SB, Kramer PL, Shalish C, de Leon D, Brin MF, Raymond D, Corey DP, Fahn S, Risch NJ, Buckler AJ, Gusella JF, Breakefield XO (1997) The early-onset torsion dystonia gene (DYT1) encodes an ATP-binding protein. Nat Genet 17:40-48. CrossRef Medline

Padovan-Neto FE, Sammut S, Chakroborty S, Dec AM, Threlfell S, Campbell PW, Mudrakola V, Harms JF, Schmidt CJ, West AR (2015) Facilitation of corticostriatal transmission following pharmacological inhibition of striatal phosphodiesterase 10A: role of nitric oxide-soluble guanylyl cyclase-cGMP signaling pathways. J Neurosci 35:5781-5791. CrossRef Medline

Paxinos G and Franklin KBJ (2012) The mouse brain in stereotaxic coordinates, fourth edition. Amsterdam: Elsevier.

Pisani A, Martella G, Tscherter A, Bonsi P, Sharma N, Bernardi G, Standaert DG (2006) Altered responses to dopaminergic D2 receptor activation and N-type calcium currents in striatal cholinergic interneurons in a mouse model of DYT1 dystonia. Neurobiol Dis 24:318-325. CrossRef Medline

Puglisi F, Vanni V, Ponterio G, Tassone A, Sciamanna G, Bonsi P, Pisani A, Mandolesi G (2013) Torsin A localization in the mouse cerebellar synaptic circuitry. PLoS One 8:e68063. CrossRef Medline

Quartarone A, Pisani A (2011) Abnormal plasticity in dystonia: disruption of synaptic homeostasis. Neurobiol Dis 42:162-170. CrossRef Medline

Querejeta E, Delgado A, Valdiosera R, Erlij D, Aceves J (2001) Intrapallidal D2 dopamine receptors control globus pallidus neuron activity in the rat. Neurosci Lett 300:79-82. CrossRef Medline

Reiner A, Albin RL, Anderson KD, D'Amato CJ, Penney JB, Young AB (1988) Differential loss of striatal projection neurons in Huntington disease. Proc Natl Acad Sci U S A 85:5733-5737. CrossRef Medline

Rondot P (1991) The shadow of movement. J Neurol 238:411-419. CrossRef Medline

Rostasy K, Augood SJ, Hewett JW, Leung JC, Sasaki H, Ozelius LJ, Ramesh V, Standaert DG, Breakefield XO, Hedreen JC (2003) TorsinA protein and neuropathology in early onset generalized dystonia with GAG deletion. Neurobiol Dis 12:11-24. CrossRef Medline

Salmi P, Chergui K, Fredholm BB (2005) Adenosine-dopamine interactions revealed in knockout mice. J Mol Neurosci 26:239-244. CrossRef Medline

Sammut S, Dec A, Mitchell D, Linardakis J, Ortiguela M, West AR (2006) Phasic dopaminergic transmission increases NO efflux in the rat dorsal striatum via a neuronal NOS and adopamine $\mathrm{D}(1 / 5)$ receptor-dependent mechanism. Neuropsychopharmacology 31:493-505. CrossRef Medline

Sammut S, Bray KE, West AR (2007) Dopamine D2 receptor-dependent modulation of striatal NO synthase activity. Psychopharmacology (Berl) 191:793-803. CrossRef Medline 
Schiffmann SN, Fisone G, Moresco R, Cunha RA, Ferré S (2007) Adenosine $A_{2 \mathrm{~A}}$ receptors and basal ganglia physiology. Prog Neurobiol 83:277-292. CrossRef Medline

Sciamanna G, Bonsi P, Tassone A, Cuomo D, Tscherter A, Viscomi MT, Martella G, Sharma N, Bernardi G, Standaert DG, Pisani A (2009) Impaired striatal D2 receptor function leads to enhanced GABA transmission in a mouse model of DYT1 dystonia. Neurobiol Dis 34:133-145. CrossRef Medline

Sciamanna G, Tassone A, Martella G, Mandolesi G, Puglisi F, Cuomo D, Madeo G, Ponterio G, Standaert DG, Bonsi P, Pisani A (2011) Developmental profile of the aberrant dopamine D2 receptor response in striatal cholinergic interneurons in DYT1 dystonia. PLoS One 6:e24261. CrossRef Medline

Sciamanna G, Tassone A, Mandolesi G, Puglisi F, Ponterio G, Martella G, Madeo G, Bernardi G, Standaert DG, Bonsi P, Pisani A (2012) Cholinergic dysfunction alters synaptic integration between thalamostriatal and corticostriatal inputs in DYT1 dystonia. J Neurosci 32:11991-12004. CrossRef Medline

Seeger TF, Bartlett B, Coskran TM, Culp JS, James LC, Krull DL, Lanfear J, Ryan AM, Schmidt CJ, Strick CA, Varghese AH, Williams RD, Wylie PG, Menniti FS (2003) Immunohistochemical localization of PDE10A in the rat brain. Brain Res 985:113-126. CrossRef Medline

Sharma N, Baxter MG, Petravicz J, Bragg DC, Schienda A, Standaert DG, Breakefield XO (2005) Impaired motor learning in mice expressing torsinA with the DYT1 dystonia mutation. J Neurosci 25:5351-5355. CrossRef Medline

Shindou T, Nonaka H, Richardson PJ, Mori A, Kase H, Ichimura M (2002) Presynaptic adenosine A2A receptors enhance GABAergic synaptic transmission via a cyclic AMP dependent mechanism in the rat globus pallidus. Br J Pharmacol 136:296-302. CrossRef Medline

Siuciak JA, Chapin DS, Harms JF, Lebel LA, McCarthy SA, Chambers L,
Shrikhande A, Wong S, Menniti FS, Schmidt CJ (2006) Inhibition of the striatum-enriched phosphodiesterase PDE10A: a novel approach to the treatment of psychosis. Neuropharmacology 51:386-396. CrossRef Medline

Soderling SH, Bayuga SJ, Beavo JA (1999) Isolation and characterization of a dual substrate phosphodiesterase gene family: PDE10A. Proc Natl Acad Sci U S A 96:7071-7076. CrossRef Medline

Standaert DG (2011) Update on the pathology of dystonia. Neurobiol Dis 42:148-151. CrossRef Medline

Thompson WJ, Appleman MM (1971) Multiple cyclic nucleotide phosphodiesterase activities from rat brain. Biochemistry 10:311-316. CrossRef Medline

Threlfell S, West AR (2013) Review: modulation of striatal neuron activity by cyclic nucleotide signaling and phosphodiesterase inhibition. Basal Ganglia 3:137-146. CrossRef Medline

Threlfell S, Sammut S, Menniti FS, Schmidt CJ, West AR (2009) Inhibition of phosphodiesterase $10 \mathrm{~A}$ increases the responsiveness of striatal projection neurons to cortical stimulation. J Pharmacol Exp Ther 328:785-795. CrossRef Medline

Uluğ AM, Vo A, Argyelan M, Tanabe L, Schiffer WK, Dewey S, Dauer WT, Eidelberg D (2011) Cerebellothalamocortical pathway abnormalities in torsinA DYT1 knock-in mice. Proc Natl Acad Sci U S A 108:6638-6643. CrossRef Medline

Xie Z, Adamowicz WO, Eldred WD, Jakowski AB, Kleiman RJ, Morton DG, Stephenson DT, Strick CA, Williams RD, Menniti FS (2006) Cellular and subcellular localization of PDE10A, a striatum-enriched phosphodiesterase. Neuroscience 139:597-607. CrossRef Medline

Yokoi F, Dang MT, Liu J, Gandre JR, Kwon K, Yuen R, Li Y (2015) Decreased dopamine receptor 1 activity and impaired motor-skill transfer in Dyt1 $\Delta$ GAG heterozygous knock-in mice. Behav Brain Res 279:202-210. CrossRef Medline 